\title{
UJI DAYA HAMBAT JAMUR ENDOFIT AKAR BAKAU ACHANTUS TERHADAP BAKTERI STAPHYLOCOCCUS AUREUS DAN ESCHERICHIAE COLI
}

\author{
${ }^{1}$ Clara Pongantung \\ ${ }^{2}$ Billy Kepel \\ ${ }^{2}$ Widdhi Bodhi \\ ${ }^{1}$ Kandidat Skripsi Fakultas Kedokteran Univerasitas Sam Ratulangi Manado
${ }^{2}$ Bagian Kimia Fakultas Kedokteran Universitas Sam Ratulangi Manado
}

\begin{abstract}
Fungi and bacteria are microbes that are classified in the general stage of Endofit. Fungi is the most isolated form of Endofit. To this point studies articulating endofit are still at a scarce stage, without a doubt the corresponding relationship between plants and organisms. Endosimbions are considered in a state between grass that grows endemic in The United States of America (truf grass) and endofit fungi, Neotyphodium SP. The purpose of these researches are to see and understand the inhibition of bacteria growth from endofit fungi that can be obtained from the roots of Mangrove Acanthus against bacteria Staphylococcus Aureus and Escherichia coli. These studies have been researched since November 2013 to January 2014 at the Biomedical Research Laboratory Faculty of Medicine University of Sam Ratulangi. The research results that were conjured from the Mangrove root type Achantus have an inhibitory effect on the test bacteria research, which are Staphylococcus Aureus and Escherichia Coli.
\end{abstract}

Keywords: endofit fungi, Achantus, Staphylococcus Aureus, and Escherichia Coli.

\begin{abstract}
Abstrak: Jamurdan bakteri merupakan mikroba yang paling umum dijumpai sebagai endofit, sedangkan endofit yang paling sering diisolasi ialah jamur. Sejauh ini penelitian mengenaiendofit masih sanga tjarang dipelajari, akan tetapi hubungan antara tumbuhan dengan organisme endosimbion dapat dilihat antara suatu jenis rumput yang tumbuh endemik di Amerika Utara (truf grass) dengan jamur endofit Neotyphodium sp. Tujuan penelitian ini untuk melihat dan mengetahui daya hambat pertumbuhan bakteri dari jamur endofit yang terdapat pada akar mangrove Acanthus terhadap bakteri Staphylococcus aureus dan Escherichia coli. Penelitian ini dilakukan sejak bulan November 2013 sampai dengan Januari 2014 di Laboratorium Riset Biomedik Fakultas Kedokteran Universitas Sam Ratulangi. Dari hasil penelitian yang didapat akar mangrove jenis achantus memiliki daya hambat terhadap bakteri uji pada penelitian ini yaitu staphylococcus aureus dan Escherichia coli.
\end{abstract}

Kata kunci: jamur endofit, Achantus, Staphylococcus aureus, Escherichiae coli.

Mikroorganisme endofit dapat ditemukan hampir di setiap tanaman di bumi. ${ }^{1,2}$ Organisme ini terdapat di dalam jaringan dan bersimbiosis dengan tanaman tersebut. $^{2}$ Endofit dapat memengaruhi tanaman dimana mereka tinggal untuk memroduksi senyawa yang bertujuan untuk melindunginya dari aktivitas predasi maupun dominasi spesies dari hubungan mutualistik diatas, ${ }^{2}$ diduga mikroorganisme endosimbion ini mampu menghasilkan senyawa dengan struktur yang unik dengan aktivitas beragam yang dapat dikembangkan sebagai bahan obat di waktu mendatang untuk mengobati berbagai macam penyakit yang dihadapi oleh manusia. ${ }^{3,4}$

Antibiotika adalah obat yang digunakan untuk mengobati infeksi bakteri pada manusia. ${ }^{5,6}$ Senyawa ini dihasilkan oleh mikroorganisme khususnya fungi atau dihasilkan secara sintetik maupun semi 
sintetik mengikuti pola struktur senyawa antibioik yang ada. Sayangnya penggunaan antibiotika yang tidak tepat dapat memicu terjadinya resistensi bakteri. ${ }^{6}$ Resistensi bakteritelah menjadi masalah terhadap internasional yang serius. Munculnya patogen yang kebal terhadap satu atau beberapa jenis antibiotika tertentu sangat menyulitkan dalam proses terapi penyakit infeksi. $^{6}$

Diversitas hayati laut Indonesia sangat menjanjikan untuk dieksplorasi dan dimanfaatkan terutama oleh masyarakat Indonesia. Biodiversitas tersebut merupkan cerminan dari tingginya biodiversitas pada level yang lebih mendasar yaitu biodiversitas genetik, biomolekuler, enzim dan senyawa kimia aktif. Pendekatan bioteknologi dengan memanfaatkan berbagai disiplin ilmu merupakan salah satu jawaban agar kekayaan laut Indonesia mangrove dapat dipelihara dan dimanfaatkan. ${ }^{7,8}$

Habitat mangrove merupakan sumber daya alam dengan produktivitas yang dapat dimanfaatkan baik dalam sektor perikanan maupun kehutanan. Habitat ini merupakan sumber alam yang kaya dan menjadi ekosistem eksotik dari berbagai flora dan fauna endemik.

Pada penelitian sebelumnya didapatkan yaitu Cryptocandin ialah anti- fungi yang dihasilkan oleh mikroba endofit Cryptosporiopsis quercina yang berhasil diisolasi dari tanaman obatTripterigeum wilfordii, dan berhasiat sebagai anti jamur yang patogen terhadap manusia yaitu Candida albicans dan Trichopyton spp, ${ }^{9}$ terhadap pemanfaatan endofit dari tanaman maka peneliti ingin melakukan penelitian endofit pada mangrove. Mangrove bertumbuh dengan baik di daerah tropis dan estuary, yang mana memiliki fungsi sebagai penyaring bahan nutrisi dan penghasil bahan organik, serta berfungsi sebagai daerah penyanggah antara daratan dan lautan.

\section{METODE PENELITIAN}

Penelitian ini merupakan penelitian eksperimental laboratorium dengan rancangan control trial, dilakukan sejak bulan November 2013 sampai dengan Januari 2014, di Laboratorium Riset Biomedik Fakultas Kedokteran Universitas Sam Ratulangi. Pengujian ini dilakukan dengan cara mengamati terbentuknya daerah jernih (clear zone) pada cawan petri dan mengukur diameter daerah jernih tersebut menggunakan kaliper.

\section{HASIL PENELITIAN DAN BAHASAN}

Pada cawan petri yang sudah di inkubasi selama 24 jam, terlihat zona hambat yang terbentuk. Untuk mengukur zona hambat pada gambar digunakan kaliper dengan cara membalikan cawan petri dan diukur diameternya. Hasil pengukuran diuraikan dalam bentuk $\mathrm{cm}$, ditabukasi dan dimasukan ke dalam rumus untuk mendapatkan hasil dari pengukuran yang dicari (Tabel 1).

Tabel 1. Diameter dan luas pertumbuhan daerah jernih

\begin{tabular}{clcccc}
\hline \multirow{2}{*}{ NO } & Diameter/ & \multicolumn{2}{c}{$\begin{array}{c}\text { Staphylococcus } \\
\text { aureus }\end{array}$} & \multicolumn{2}{c}{ Eschericia coli } \\
& & Hitam & Hijau & Hitam & Hijau \\
\hline \multirow{2}{*}{ I } & Diameter & 1,80 & 1,50 & 1,80 & 1,40 \\
& Luas & 2,54 & 1,77 & 2,54 & 1,54 \\
\multirow{2}{*}{ II } & Diameter & 1,70 & 1,60 & 1,70 & 1,80 \\
& Luas & 2,27 & 2,01 & 2,27 & 2,54 \\
\multirow{2}{*}{ III } & Diameter & 1,80 & 1,50 & 2,00 & 2,00 \\
& Luas & 2,54 & 1,77 & 3,14 & 3,14 \\
IV & Diameter & 1,90 & 2,00 & 2,10 & 2,50 \\
& luas & 2,83 & 3,14 & 3,46 & 4,91 \\
\multirow{2}{*}{ V } & Diameter & 1,70 & 1,80 & 1,90 & 2,00 \\
& luas & 2,27 & 2,54 & 2,83 & 3,14 \\
Rata & Diameter & 1,78 & 1,68 & 1,90 & 1,94 \\
-rata & Luas & 2,49 & 2,25 & 2,85 & 3,05 \\
\hline
\end{tabular}

Keterangan : diameter $(\mathrm{cm})$, luas $\left(\mathrm{cm}^{2}\right)$ 
Tabel 2. Luas diameter pertumbuhan jamur

\begin{tabular}{clcccc}
\hline \multirow{2}{*}{ NO } & Diameter/ & \multicolumn{2}{c}{$\begin{array}{c}\text { Staphylococcus } \\
\text { aureus }\end{array}$} & \multicolumn{2}{c}{ Eschericia coli } \\
& \multicolumn{1}{c}{ Luas } & Hitam & Hijau & Hitam & Hijau \\
\hline \multirow{2}{*}{ I } & Diameter & 0,70 & 0,90 & 0,80 & 0,80 \\
& Luas & 0,38 & 0,64 & 0,50 & 0,50 \\
\multirow{2}{*}{ II } & Diameter & 0,70 & 0,90 & 0,80 & 0,90 \\
& Luas & 0,38 & 0,64 & 0,50 & 0,64 \\
III & Diameter & 0,70 & 0,90 & 0,80 & 0,90 \\
& Luas & 0,38 & 0,64 & 0,50 & 0,64 \\
IV & Diameter & 0,70 & 0,90 & 0,80 & 0,80 \\
& luas & 0,38 & 0,64 & 0,50 & 0,50 \\
\multirow{2}{*}{ V } & Diameter & 0,70 & 0,90 & 0,80 & 0,70 \\
& luas & 0,38 & 0,64 & 0,50 & 0,38 \\
Rata & Diameter & 0,70 & 0,90 & 0,80 & 0,82 \\
-rata & Luas & 0,38 & 0,64 & 0,50 & 0,53 \\
\hline
\end{tabular}

Keterangan : diameter $(\mathrm{cm})$, luas $\left(\mathrm{cm}^{2}\right)$

Table 3. diameter dan luas kontrol (+) pada bakteri uji

\begin{tabular}{lccc}
\hline \multicolumn{1}{c}{ Bakteri Uji } & Jamur & $\begin{array}{c}\text { Kontrol } \\
(+)\end{array}$ & $\begin{array}{c}\text { Lua } \\
\text { s }\end{array}$ \\
\hline staphylococcus & Hitam & 3,0 & 7,1 \\
aureus & Hijau & 2,9 & 6,6 \\
escherichia coli & Hitam & 3,4 & 9,1 \\
Rata-rata & Hijau & 3,0 & 7,1 \\
& & 3,1 & 7,5 \\
\hline
\end{tabular}

$\overline{\text { Keterangan :Kloramfenikolsebagai control (+), }}$ Diameter $(\mathrm{cm})$, luas $\left(\mathrm{cm}^{2}\right)$

Table 4. Luas zona hambat

\begin{tabular}{|c|c|c|c|c|c|c|c|}
\hline \multirow{2}{*}{$\begin{array}{c}\text { Bakteri } \\
\text { Uji }\end{array}$} & \multicolumn{5}{|c|}{ Luas zona hambat } & \multirow{2}{*}{$\begin{array}{c}\text { Kontrol } \\
(+)\end{array}$} & \multirow{2}{*}{ Luas } \\
\hline & I & II & III & IV & V & & \\
\hline \multirow{2}{*}{ SA } & 2,2 & 1,9 & 2,2 & 2,4 & 1,9 & 3,0 & 7,1 \\
\hline & 1,1 & 1,4 & 1,1 & 2,5 & 1,9 & 2,9 & 6,6 \\
\hline \multirow{2}{*}{$\mathrm{EC}$} & 2,0 & 1,8 & 2,6 & 3,0 & 2,3 & 3,4 & 9,1 \\
\hline & 1,0 & 1,9 & 2,5 & 4,4 & 2,8 & 3,0 & 7,1 \\
\hline SD & 0,6 & 0,2 & 0,7 & 0,9 & 0,4 & 0,2 & 1,1 \\
\hline
\end{tabular}

\section{SIMPULAN}

Dari hasil yang di dapat akar mangrove jenis Achantus memiliki daya hambat terhadap bakteri uji pada penelitian ini yaitu Staphylococcus aureus dan Escherichia coli.

\section{SARAN}

Diharapkan dapat dilakukuan penelitian lebih lanjut tentang efek antibakteri dari akar mangrove jenis Achantus ini, dan pengujian pada bakteri yang lain.

\section{DAFTAR PUSTAKA}

1. Noverita, Fitria D, Sinaga E. Isolasi dan uji aktivitas antibakteri jamur endofit dari daun dan rimpang Zingiberottensii. Fakultas Biologi UniversitasNasional, Jurnal Farmasi Indonesia. 2009;4(4): 171-6.

2. Strobel G, Bryn D, Uvidelio C, Harper J. Natural Products from Endophytic Microorganisms. Department of Plant Sciences,Montana State University, Bozeman, Montana 59717, and Department of Chemistry, University of Utah, Salt Lake City, Utah 84112. 2004: p. 257.

3. Radji M. Peranan bioteknologi dan mikroba endofit dalam pengembangan obat herbal. Laboratorium Mikrobiologi dan Bioteknologi Departemen Farmasi, FMIPA-UI, 2005: p. 113-26.

4. Maksum R. Pemberian Vaksin melalui Tanaman Transgenik. Maj. Il. Kefarmasian Indon. 2004:1-9.

5. Kumala S, Indriani D. Efek antibakteri ekstrak etanol daun cengkeh (Eugenia aromatic L.), Fakultas Farmasi Universitas Pancasila. JurnalFarmasi Indonesia. 2008;4 (2):82.

6. Utami ER. Antibiotika, resistensi, dan rasionalitas terapi. Fakultas Sains dan Tekhnologi UIN Maliki Malang, 2012.

7. Hakim L. Konservasi Biodiversitas Indonesia. Program Pascasarjana Univesitas Brawijaya, 2013.

8. Soeroyo. Sifat Fungsi dan Peranan Hutan Mangrove, Jl. PasirPutih, AncolTimur, Jakarta.

9. Satria Oktavianus.Uji daya hambat ekstrak daun mangrove jenis avicennia marina terhadap bakteri vibrio parahaemolyticus [Skripsi]. Jurusan ilmu kelautan Fakultas Ilmu Kelautan dan Perikanan Universitas Hasanuddin Makassar. 2013. 